\title{
Javaslat a terhesgondozás és perinatológiai ellátás egységes minőségkontrollját célzó, Europeristat-konform adatszolgáltatási rendszer bevezetésére Magyarországon
}

\begin{abstract}
Berkő Péter dr. ${ }^{1,2}$
${ }^{1}$ Miskolci Egyetem, Egészségügyi Kar, Miskolc

${ }^{2}$ Borsod-Abaúj-Zemplén Megyei Kórház és Egyetemi Oktatókórház, Szülészeti és Nőgyógyászati Osztály, Miskolc

A magyar egészségügynek sajnálatos fogyatékossága, hogy nem (vagy csak 1-2 szakma területén, l-2 klinikán, l-2 osztályon) alakult még ki a gyógyítómunka minőségkontrolljának kultúrája és rendszere. Ha a kórházi osztályoknak nincs országos, szakmánként egységes, korszerü, a gyógyítómunkájuk legfontosabb mennyiségi és minőségi mutatóit évente bemutató adatszolgáltatási rendszere, akkor nincs lehetőség a munkaszínvonal alakulásának, tendenciáinak elemzésére, nincs biztos alap a jövő feladatainak a meghatározásához. A szerző javaslatot tesz ilyen, szakmánként kialakított adatszolgáltatási rendszerek létrehozatalára. A Borsod-Abaúj-Zemplén megyében 3 évtizede folyó perinatológiai adatszolgáltatási rendszer tapasztalatai alapján konkrét javaslatot tesz továbbá az eddigi Tauffer-statisztikát felváltó, országosan egységes, a terhesgondozás és perinatológiai ellátás egységes minőségkontrollját megvalósító, Europeristat-konform adatszolgáltatási rendszer és az ennek alapját képezó adatlap, a „Terhesgondozás és Perinatológiai Ellátás Rizikó Adatlapja (TePERA)” bevezetésére. Orv. Hetil., 2016, 157(18), 687-694
\end{abstract}

Kulcsszavak: Europeristat, minőségkontroll, perinatológiai adatszolgáltatási rendszer

\section{A proposal for introduction of Europeristat-compatible information system aiming a unified quality control of obstetrical and perinatological care in Hungary}

It is a regrettable deficiency in the Hungarian healthcare that the culture and the system of quality control of cure have not been formed (except for a few subspecialties, units or wards). If hospital wards do not have a national, professionally unified and modern information system presenting the most important quantity and quality indicators of their medicinal activity annually, a stable basis for definition of future tasks is absent. The author puts forward a proposal for the establishment of the information systems for different professional fields. On the basis of experience of perinatological information system operating for over 3 decades in Borsod-Abaúj-Zemplén county, he also proposes introduction of a nationally unified, Europeristat-compatible information system following Tauffer-statistics which may serve as a uniform quality control of obstetrics and perinatological care, as well as introduction of its base, the dataform "TePERA" (Form of Obstetrics and Perinatological Care Risk).

Keywords: Europeristat, quality control, perinatological information system

Berko", $P$. [A proposal for introduction of Europeristat-compatible information system aiming a unified quality control of obstetrical and perinatological care in Hungary]. Orv. Hetil., 2016, 157(18), 687-694.

(Beérkezett: 2016. január 28.; elfogadva: 2016. február 25.) 
A magyar egészségügynek sajnálatos fogyatékossága, hogy nem (vagy csak 1-2 orvosi szakma területén, 1-2 klinikán, 1-2 osztályon) alakult még ki [1] a gyógyítómunka korszerü minőségkontrolljának kultúrája és rendszere. Ez a hiányosság jelentősen fékezi gyógyítómunkánk színvonalának javítását, eredményesebbé tételét. Gondoljunk csak bele! Vajon van-e az ország, a megyék, a járások és nagyobb városok egészségügyi ellátásért (is) felelős vezetőinek megbízható(!) információi arról, hogy: 1. Melyek a felügyeletükre, gondjaikra bízott lakosság egészségi állapotának fó jellemzői (például átlagéletkor; legfontosabb haláloki betegségek; népegészségügyi szempontból legfontosabb és leggyakoribb betegségek; a rokkantsághoz és keresóképtelenséghez leggyakrabban vezető betegségek stb.)? 2. Megfelel-e az ország, megye, város egészségügyi ellátórendszerének struktúrája az adott terület valós szükségleteinek? Hol és mely szakterületeken vannak hiányzó vagy éppen felesleges kapacitások? 3. Milyen hiányosságai vannak az ellátórendszer szakmai munkája feltételrendszerének (épület, mûszerek-eszközök, gyógyszerek, munkaerő, múködtetés stb.)? 4. Milyen a gyógyítómunka színvonala, eredményessége az egyes intézményekben, osztályokon, illetve megyékben és városokban (gyógyulási esélyek, fontosabb szövődmények előfordulása, halálozás stb.)? 5. Melyek a legfőbb hibák és hiányosságok, amelyeken javítani, változtatni kellene? 6. Vannak-e, és ha igen, akkor mit mutatnak az egyes megyék és kórházak egymásnak megfelelő osztályai eredményeinek összehasonlító vizsgálatai? Meggyőződésem: ha a gyógyítómunkának nincs a kor követelményeinek megfelelő és megbízható minőségkontrollja, akkor nincs reális esélye annak, hogy az eredményeken javítani lehessen. Akkor nem lehet reális alapja a tervezésnek és a valós szükségletekhez igazodó fejlesztéseknek. - Valljuk be őszintén: az egészségügyi ellátás felelős vezetőinek többsége nem tudna ezekre a kérdésekre válaszolni. Ennek fó oka az, hogy nincs olyan, minden szakterületre kiterjedő minőségkontroll-rendszerünk, amely lehetővé tenné ezeknek a kérdéseknek a megválaszolását.

Ha egy osztályvezető nem tudja azt, hogy évenkénti rendszerességgel felmérve: 1. Milyenek az osztálya munkájának minőségmutatói (gyógyulási arányok, legfőbb szövődmények, halálozás stb.)? 2. Milyenek az eredmények a korábbi évek eredményeivel összevetve? 3. Milyenek az eredmények más kórházak hasonló osztályai eredményeivel összehasonlítva? Nos, ha ezekre a kérdésekre nem tud válaszolni, akkor nehezen fogja tudni eldönteni, hogy az eredmények javítása érdekében mit kellene a jövőben másként, jobban csinálni az osztályán. Ha a kórházi osztályvezetők nem törekszenek munkájuk minőségének, eredményességének időről időre történő felmérésére, akkor a kórház igazgatójának sincs lehetősége korrekt minőségmutató paraméterekre alapozott véleményt mondani az egyes osztályokon folyó szakmai munka eredményességéről, nincs lehetősége kedvező vagy kedvezőtlen tendenciák felismerésére, az osztályve- zetés színvonalának korrekt véleményezésére. Márpedig - ismereteim szerint, osztályvezető kollégáimtól szerzett információk alapján - ez a helyzet, de legalábbis ez a jellemző. És ez nagy baj, komoly hiányosság! Ezek a hiányosságok rávilágítanak és igazolják, hogy a magyar egészségügyből nem csak a pénz hiányzik.

\section{1. javaslat - minden szakmát érintően - az egyes szakmákon belül egységes, országos adatszolgáltatási rendszer - mint minőségkontroll - bevezetésére}

Az országosan egységes, de szakterületenként egymástól különböző, az adatszolgáltatás rendszerére épülő minőségkontroll megvalósítása egyszerüen megoldható, költségigénye sem számottevő. A szakmai és tudományos szempontból minősíthető haszna ugyanakkor beláthatatlanul nagy. Minden szakmának van szakmai kollégiumi tanácsadó testülete. E testületeket kellene felkérni arra, hogy állítsák össze:

l. a szakmájukhoz tartozó klinikák és osztályok tevékenységét, leterheltségét, járó- és fekvőbeteg-forgalmát, a szakterületükhöz tartozó, népegészségügyi szempontból legfontosabb betegségek előfordulási gyakoriságát, és a munkájuk feltételrendszerének meglétét, illetve hiányosságait tükröző „mennyiségi mutatók” rendszerét, továbbá

2. az egyes klinikák és osztályok munkája színvonalát tükröző „minőségi mutatók” listáját is. Nem kellene sokat markolni, csupán a legfontosabb minőségi mutatók kiemelésére lenne szükség. Például: a gyógyítómunka sikerét vagy sikertelenségét, a halálozás és a leggyakoribb, illetve legfontosabb szövődmények gyakoriságát stb. tükröző adatokra.

Az eredmények számszerűsíthetők, grafikonon is ábrázolhatók, így az évről évre történő adatfeldolgozás eredményeként a lényeges változások és tendenciák minden mennyiségi és minőségmutató paraméter esetében könynyen felismerhetők lennének. Az adatokat online, évente, központi szerverre kellene eljuttatni, osztályonként és összesítve feldolgozni, majd átadni a kollégiumi tanácsadó testületeknek, hogy minősítsék az észlelhető tendenciákat, az osztályvezetők orientálása érdekében hozzanak állásfoglalásokat, tegyenek javaslatokat a felismert hiányosságok, hibák, káros tendenciák felszámolása érdekében.

Azt hiszem, ez a minőségkontrollt megvalósító adatszolgáltatási rendszer kiválthatna többféle, jelenleg forgalomban lévő, sok gondot okozó és sok időráfordítást igénylő adatszolgáltatási formulát is, de ami a legfontosabb: jelentős mértékben járulhatna hozzá az egészségügyi ellátórendszer munkája színvonalának és eredményességének javulásához. - Nem értek egyet azokkal, akik azt gondolják, és örökösen csak azt harsogják, hogy a magyar egészségügy színvonalának javítása pénz, pénz és csakis több pénz kérdése. Ami igaz, az igaz: az eddigi- 
nél jóval többet kellene az egészségügyre költeni. De a minőségkontroll kiépítése szükségességének gondolata - úgy vélem - jó példa arra, hogy messze nem csak a pénz hiányzik. Talán néhány ötlet, néhány gondolat, javaslat, néhány, pénzbe alig kerülő, de sok hasznot hozó kezdeményezés.

Tájékozódtam, a Miskolci Egyetem és Egészségügyi Kara rendelkezik olyan informatikai személyi feltételekkel és számítógépes kapacitással, amelyek - némi minisztériumi támogatással - bázisát képezhetnék egy, akár több szakterületet érintő, országos adatfeldolgozó rendszernek.

\section{2. javaslat a terhesgondozás és perinatológiai ellátás egészét átfogó minőségkontroll, egy Europeristat-konform(!) adatszolgáltatási rendszer bevezetésére}

Az előzőekben leírtak szellemében konkrét javaslatot teszek a terhesgondozás és a perinatológiai ellátás Europeristat-konform új adatszolgáltatási rendszerének bevezetésére.

Tapasztalataim hosszú időre nyúlnak vissza. A BorsodAbaúj-Zemplén Megyei Kórházban még 1983-ban, immár 32 éve bevezettük az akkor általam, beosztott főorvosként kidolgozott és javasolt perinatológiai adatlapok alkalmazását. Minden, osztályunkon megszületett magzat számára perinatológiai adatlapot töltöttünk ki, amely az osztály neonatológusának kezébe jutott. Ha az újszülöttet át kellett helyeznünk a koraszülöttosztályra, akkor a lapot is átküldtük az újszülöttel. A perinatológiai adatlap sokoldalúan informálta a neonatológusokat a várandós nő és a magzat sorsát befolyásoló rizikótényezőkről, a terhesség és a szülés alatt történtekről, az újszülött állapotáról, a vele történtekről és az áthelyezés okáról.

1984-ben, az addig szerzett tapasztalatok felhasználásával, az adatlapot (Gaál József tanár úr közremúködésével) továbbfejlesztettük. Az én megyei kórházi osztályvezetői kinevezésemet (1997) követően bevezettük a Borsod-Abaúj-Zemplén megyének mind a 7 szülészeti osztályára kiterjesztett, teljes körü, megyei perinatológiai adatszolgáltatás (és számítógéppel történő adatfeldolgozás) rendszerét. Az egyes szülészeti osztályokon és az egész megyében élve vagy halva született valamennyi magzat, illetve újszülött terhességi előzményeit, születésével és újszülöttkori állapotával kapcsolatos adatokat számítógépen feldolgozva rendkívül értékes adatokat nyertünk. Ezeket az akkor még havonta megtartott szülészfőorvosi értekezleteken és az akkor még évente megrendezett megyei anya- és csecsemővédelmi értekezleteken ismertettük. Ezek ismeretében igyekeztünk meghatározni a következő év legfontosabb szakmai (terhesgondozás, szülészeti és neonatológiai-gyermekgyógyászati ellátás) feladatait. - Megtettük ugyanezt a megye onkoginekológiai betegei ellátása vonatkozásában is.
Valószínúleg mi voltunk az egyetlen megye, ahol pontos adatokkal rendelkeztünk az egyes nőgyógyászati rákféleségek évenkénti előfordulását, ellátásának mikéntjét és az öt éven át követett betegek sorsát illetően.

A közelmúltban megismertem az Europeristat adatszolgáltatás rendszerét, és ennek interneten is hozzáférhető (European Perinatal Health Report, 2010) eredményeit [2]. Az Európai Unió tagországaitól bekért és bemutatott perinatológiai adatsort és táblázatokat áttekintve, megdöbbenve tapasztaltam, hogy a Magyarországról beküldött adatsor milyen nagymértékben hiányos. Nem kétséges, hogy ez a hiányosság más európai országok szülészorvosai előtt kedvezőtlen színben jeleníti meg hazánkat. Ítélje meg az Olvasó!

Íme, azok a kérdések, amelyekre Magyarország - ilyen adatok szolgáltatásának és kimutatásának hiányában nem tudott választ adni:

Terhesgondozás kezdete (I. trimeszter, II. trimeszter, III. trimeszter, nem járt gondozásra)?

- Anya életkora (<20, 20-24, 25-34, 35+)?

- Anya iskolai végzettsége ( $<8$ osztály, általános, középfokú, felsőfokú)?

- Dohányzók aránya?

- „Nacionality” (más országban született anya), „etnicity" (melyik etnikumhoz tartozik)"? (Talán meglepo", de az EU 28 tagországa közül csak a belga, görög, magyar, román, szlovák, szlovén és izlandi adatok hiányoznak! Csak ezekben az országokban nem lehet a származásra rákérdezni!? Az Amerikai Egyesült Államokban és számos más, fejlett” országban ez lehetséges, mondhatni természetes! Akkor nálunk - természetesen önkéntes bevallás alapján - miért is nem lebetséges?)

- Ikerszülés/1000 szülőnő?

- Többes szülések (III., IV., V., VI.) száma/1000 szülőnő?

- Meddőségkezelés utáni szülés (IVF, ICSI, IVM, FET, inseminatio, csak ovarium indukció, egyéb)? (IVM = in vitro maturation, FET = fagyasztott preembriótranszfer.)

- A szülés a progresszív ellátás melyik szintjéhez tartozó intézetben történt?

- Évi <500, 500-1499, 1500-2999, 3000-4999, 5000+ szülést levezető osztályon, továbbá: I., II., III. szintü intézetben, illetve I. szint alatt (otthon, mentőben, szülőotthonban)?

- Anyai terhesség alatti morbiditás fó típusai?

- Anyai morbiditás (eclampsia, post partum vérzés miatti hysterectomia)/1000 szülőnőre?

- Szülés indulása (spontán, indított, elektív császármetszés)?

- Szülés módja (spontán hüvelyi, császármetszés, instrumentált hüvelyi). Mi az utóbbit nem tudjuk megválaszolni.

- Császármetszés típusa (vajúdás megindulása előtt, vajúdás alatt)?

- Episiotomia történt-e? 
- III-IV. fokú gátrepedés előfordulása?

- Apgar 5' - <4, 4-6 előfordulása?

- Emlőre helyezés 24 órán belül?

- Anyai mortalitás az anya életkora szerint $(<25,25-$ $34,35+)$ ?

- Anyai halálozás fó okai (extrauterin graviditás, spontán abortusz, magas vérnyomás, elvérzés, chorioamnionitis/szepszis, thromboembolia, magzatvíz-embolia, aneszteziológiai szövődmény, méhrepedés, egyéb ismert ok, egyéb nem ismert ok, aspecifikus, szülészeti ok/ismeretlen ok)?

- Újszülöttek halálozása a <24., 24-27., 28-31., 3236., 37+ héten születettek körében? Fejlődési rendellenességgel társult perinatalis mortalitás?

- Fejlődési rendellenesség az újszülöttként elhaltak között?

- Együttszülés gyakorisága?

- „Bababarát ellátás” gyakorisága?

Ne tagadjuk - az adatszolgáltatás rendezetlensége és hosszabb ideje tapasztalható fegyelmezetlensége miatt még a lejelentett anyai halálesetek számában sem lehetünk biztosak. Kérdezhetné valaki: ha ezekre a kérdésekre nem tudunk válaszolni, akkor melyekre tudunk? Elkeserítő, hogy az egykor világviszonylatban is legjobb példát mutató országban, a „Szülészeti Rendtartást” [3, 4] kidolgozó és megszervező néhai Tauffer Vilmos hazájában ott tartunk, hogy - a kissé már „lejárt szavatossági idejü" és az adatgyưjtés hiányosságai miatt már hosszabb ideje nem is megbízható - 1934-ben elindított „Taufferstatisztika" $[3,4]$ után nincs korszerü, a mai szakmai és tudományos igényeknek is megfelelő perinatológiai adatszolgáltatási rendszerünk. Olyan adatszolgáltatási rendszer, amely az Europeristat elvárásait [2] is teljesíteni tudná. Nagy baj lenne, ha ebbe beletörődnénk, ha lemondanánk a nemzetközi összehasonlító vizsgálatokban való részvétel, a korrekt és hiánytalan adatszolgáltatás lehetőségéről. Ha nem igényelnénk azt, hogy jövőbeni feladataink meghatározásakor a saját osztályunk, megyénk és országunk legfontosabb perinatológiai adatainak ismeretére támaszkodhassunk.

Úgy vélem, hogy a saját kórházunkban és megyénkben több mint három évtizede sikerrel végzett perinatológiai adatgyưjtés és -feldolgozás kellő szakmai és erkölcsi alapot nyújt ahhoz, hogy egy új, eurokonform országos perinatológiai adatszolgáltatási rendszer megalkotását és bevezetését kezdeményezzem. És bemutassam azt a - neonatológusokkal is egyeztetett - adatlapot, amely - esetleges jobbító módosításokkal kiegészítve alkalmas lehet egy ilyen adatszolgáltatási rendszer múködtetéséhez (az adatlapot lásd a dolgozat végén).

Javaslom, hogy az adatszolgáltatásnak két lépcsője legyen.

1. Perinatológiai Adatlap („Terbesgondozás és Perinatológiai Ellátás Rizikó Adatlapja - röviden: TePERA)" vezetése minden(!) bekövetkezett és megtartani kívánt terhesség esetében. Ezt az adatlapot (a várandós nő gondozáson történő első megjelenésekor) a védőnő indítsa el a számára megjelölt kérdések megválaszolásával. Az általa kitöltött adatlapot adja át a terhes nőnek, ő az adatlapot tartsa a gondozási könyvében! Tegyen bejegyzést a háziorvos, majd a gravida gondozását felelősen irányító, felügyelő szülész szakorvos (aki lehet az illetékes rendelőintézet szakorvosa, kórházi ambulancia szakorvosa, magánrendelő szakorvos vagy akár a „szülés levezetésére" is felkért szakorvos is), a szülést vezető orvos, a szülészeti osztály neonatológusa, végül pedig a zárójelentést kiadó szülészorvos. Ha az újszülöttet neonatológiai osztályra kell áthelyezni, akkor az újszülött távozásakor vagy boncleletének ismeretében tegyen bejegyzést a NIC neonatológusa - majd juttassa vissza az adatlapot arra a szülészeti osztályra, ahol a gyermek született! A lezárt adatlapot végül az anya kórlapjában kell elhelyezni.

A perinatológiai adatlap bevezetésének célja, hogy (1) informálja a terhes, majd megszült nôt és az újszülöttet egymást követốn ellátó szakembereket az elözményekről, a legfőbb veszélyeztető tényezőkről, a terhesség és szülés alatt történtekről, valamint az újszülött ellátásával és sorsával kapcsolatos tudnivalókról. (2) Másodlagos célja, hogy rögzitse azokat az adatokat, amelyeket (lásd a következő pont alatt) a szülészeti osztályról - az online adatszolgáltatás keretében - az országos perinatológiai adatfeldolgozás szerveréhez kell majd továbbítani.

Kevésbé jó megoldásnak, de elképzelhetőnek tartom azt is, hogy az adatlap „elindítása” - az előzményekre és terhesség alatt történtekre vonatkozó rákérdezéssel csak a szülészeti osztályra, illetve csak a szülöszobára történófelvétel kapcsán történjen meg. Ebben az esetben kiesne a védőnő és a háziorvos direkt részvétele az adatszolgáltatásból, így a teljes anamnézis felvétele a szülészeti, illetve szülőszobai felvevő orvos feladatává válna. Nem kellene viszont félteni az adatlapot attól, hogy a várandós nő elveszíti, összegyüri, beszennyezi azt.

2. Online adatszolgáltatás a központi szerverbez. A szülészeti osztályra visszaérkező, az anya kórlapjában elhelyezett adatlapról az osztály erre betanított adminisztrátora a kijelölt adatközpont internetes honlapjára vigye be az adatokat és továbbítsa azokat (legalább havi rendszerességgel) folyamatosan a központi szerverre. Ezt követően helyezze vissza az adatlapot az anya kórlapjába!

\section{Az online perinatológiai adatszolgáltatási rendszer célja}

1. A bekövetkezett és megtartani kivánt terhességek sorsának (spontán vetélés, graviditas extrauterina, koraszülés, érett szülés, magzati, újszülött-, perinatalis és anyai halálozás) hiánytalan számbavétele.

2. A várandós nő, a szülőnő és az újszülött ellátásában részt vevő orvosok informálása az előzményben történtekről.

3. Az egyes szülészeti és neonatológiai osztályok saját szakmai tevékenysége egységes minöségkontrolljának megvalósítása. 
4. Az egyes osztályok és megyék szakmai eredményei összehasonlitó vizsgálatainak lehetővé tétele.

5. A perinatológiai tevékenység eredményei és színvonala országos szinten történó értékelésének lehetôvé tétele, és ezzel az eredmények javítását célzó további feladatok kijelölésének megkönnyítése.

6. A terhesgondozás és perinatológiai tárgyú kutatótevékenység jobb feltételeinek biztosítása.

7. Végezetül pedig - de egyáltalán nem utolsósorban biánytalan adatszolgáltatás biztositása az Europeristat nemzetközi összehasonlitó adatfeldolgozás számára.

\section{Az új adatszolgáltatási rendszerrel kapcsolatban fontos követelmény}

1. Minden adatszolgáltató hozzájuthasson az általa szolgáltatott adatok összesítéséhez, és felhasználhassa azokat a saját osztályán végzett feladattervező és kutatási tevékenységhez.

2. Biztositani kell az országos és megyei adatok elérbetöségét is, minden adatszolgáltató számára.

3. Hasznosnak és ezért szükségesnek tartanám, ha - országos szülészeti intézet hiányában - a szakmai kollégium tanácsadó testülete minden év elején kiértékelné a perinatológiai adatszolgáltatási rendszer feldolgozott, előző évi eredményeit, és megjelölné azokat a szakmai-pezetési feladatokat, amelyek az eredmények további javitását célozzák.

4. Az itt bemutatott adatlap a sorszámozott, de üresen hagyott sorokkal lehetőséget biztosít minden intézet számára, hogy az országosan gyújitött adatokon kívül néhány, saját intézményük számára (például kutatási célból) fontosnak tartott rizikótényezőre, diagnózisra vagy beavatkozásra is rá lehessen kérdezni, és azokat is fel lehessen dolgozni.

5. Ez az adatlap és adatszolgáltatási rendszer - a megfelelő, átgondolt szabályozást követően - feleslegessé tenné a hasonló, egyéb statisztikai adatlapok kitöltését, lehetővé tenné a felesleges párhuzamosságokat jelentő és nem kevés pluszmunkát igénylő adatszolgáltatások kiküszöbölését.

6. Fontos követelmény, hogy a bevezetésre javasolt új adatszolgáltatási rendszer minden vonatkozásban megfeleljen az érvényben lévö adatvédelemi elöirások$n a k ! \mathrm{Az}$ adatlap esetében nem jelenthet gondot, hogy a gravida, illetve szülőnő, valamint az újszülött az adatlap adatai alapján beazonosítható, hiszen, miután az újszülött távozott a kórházból, az adatlap visszakerül a szülészeti osztályra, és ott az anya kórlapjába tartozó dokumentumként fogják tárolni. Az adatlapon rögzített adatok közül a központi szerverhez történő online továbbítás során csakis olyan adatokat kell továbbítani és feldolgozni, amelyek alkalmatlanok arra, hogy az anya és az újszülött személye beazonosítható legyen.

\section{Az új adatszolgáltatási rendszer bevezetésének feltételrendszere}

1. Legfontosabb, hogy a szülészeti és neonatológiai szakma vezetôi egyetértsenek abban, hogy ennek az adatszolgáltatási rendszernek a bevezetésére szükség van.

2. Természetesen szükséges az is, hogy kezdeményezésünket az Egészségügyért Felelös Államtitkárság megismerje, jelentöségét megértse és támogassa.

3. Szükség van egy, az ország minden szülészeti osztályáról beérkezó adatok fogadását és feldolgozását lebetöpé tevő szerverve, és a szervert befogadó, az adatfeldolgozást biztosító egészségügyi intézményre. Ez utóbbi feladat ellátását a Miskolci Egyetem Egészségügyi Kara örömmel vállalja.

4. Anyagi támogatás szükséges az adatszolgáltatási rendszer múködéséhez szükséges három szoftver kidolgozásáboz és megvásárlásához:

a) Szoftvert kell telepiteni az ország minden szülészeti és neonatológiai osztályára (a szülószobákon és a NIC-ekben telepitett számitógépekre), amely alkalmas arra, hogy segítségével 1 percen belül meg lehessen állapítani az egyes újszülöttek érettségét, súly- és hosszfejlettségét, valamint tápláltságát mutató ÉFT-indexét [5-7], mert ezt az indexet az adatlapon is rögzíteni kell.

Az ÉFT-indexnek öt adata van: 1 . Az újszülött neme $(\mathrm{N})$ : fiú vagy lány. 2. Az újszülött betöltött hetekben mért gesztációs kora (K). 3. Az újszülöttek nemének, gesztációs korának és testsúlyértékének betáplálásával a Joubert-Zsákai-Berkó-féle magyar születési súlystandardon $[4,7]$ kiszámított súlystandard-pozíciója (S). 4. Az újszülött hosszstandard-pozíciója $(\mathrm{H}) .5$. Az újszülött tápláltsági állapotát tükröző mutató $(\mathrm{T})$, amelynek kiszámítása: $\mathrm{T}=\mathrm{S}-\mathrm{H}$.

Ezeknek a részben betáplált, részben pedig kiszámított adatoknak az ismeretében a szoftver elhelyezi az újszülöttet az általam kidolgozott ÉFT-mátrixon [57], amely lehetővé teszi az újszülött testi fejlettségétől és tápláltsági állapotától függő osztályozását és rizikóstátuszának feltüntetését.

b) A másik szoftver a szülészeti osztályok ezzel a feladattal megbizott adminisztrátora számára szükséges. Ennek segítségével - az egyes esetek (adatlapok) lezárását (az anya és az újszülött kórházból történt távozását vagy halálát) követően - az adatlapokon rögzített (bejelölt) adatokat kell online továbbitani a központi szerverhez.

c) A harmadik szoftver a szerverhez beküldött és összegyüjtött adatok - tetszőleges kérdéskombinációk megválaszolását lehetővé tevő - feldolgozásáboz szü̈kséges. Ez a szoftver teszi lehetővé:

1. az Europeristat kérdéseinek megválaszolását;

2. a legfontosabb, országos perinatológiai mutatók megismerését;

3. az egyes, adatszolgáltató osztályok általuk kért adatainak feldolgozását és kimutatását; 
4. országos, megyei és helyi szintű perinatológiai kutatómunka elősegítését.

Ennek az adatszolgáltatási rendszernek a megvalósítása és múködtetése természetesen igényel némi anyagi ráforditást. Remélhető, hogy az Egészségügyért Felelős Államtitkárság megértéssel fogadja e kezdeményezést és támogatja is azt. Az adatszolgáltatási rendszer bevezetése elött az adatlapot - vélhetően - „tökéletesíteni”, majd véglegesíteni szükséges. Ehhez az államtitkárságnak elismert szülészorvosokból és neonatológusokból, valamint védőnőkből és háziorvosokból álló szakértői bizottságot kellene kijelölni, illetve felkérni.

\section{Következtetések}

A fentiek alapján javaslom egy minden orvosi szakterületre kiterjedő minőségkontroll, egy szakmánként egységes adatszolgáltatási rendszer bevezetését Magyarországon. Ezenkívül több évtizedes, kedvező BorsodAbaúj-Zemplén megyei tapasztalatok alapján, konkrét javaslatot teszek egy olyan perinatológiai adatszolgáltatási rendszer bevezetésére, amely a „Terhesgondozás és Perinatológiai Ellátás Rizikó Adatlapja (TePERA)" kérdéseinek - minden magzat, illetve újszülött esetében történő - megválaszolásával, majd a válaszok időről időre történő feldolgozásával lehetőséget biztosítana a megtartani kívánt terhességek sorsának, a terhességet veszélyeztető rizikótényezők, szövődmények, a legfontosabb császármetszés-javallatok előfordulásának felmérésére; lehetőséget teremtve a különböző rizikótényezők, valamint a magzat, az újszülött és az anya sorsa közötti öszszefüggések kutatására; továbbá arra is, hogy a jövőben Magyarország hiánytalan adatszolgáltatással kapcsolódhasson az Europeristat adatfeldolgozási rendszerhez. De ami talán még ezeknél is fontosabb: a TePERA adatszolgáltatási rendszer korszerú minőségkontrollt biztosítana a hazai és az egyes osztályokon folyó perinatológiai (szülészeti és neonatológiai) tevékenység színvonalának ellenőrzéséhez, a jövőbeni feladatok meghatározásához.

\section{Köszönetnyilvánítás}

Hálás köszönettel tartozom mindazon kollégáknak, akik Borsod-Abaúj-Zemplén megyében a perinatológiai adatszolgáltatás és -feldolgozás rendszerét immár évtizedek óta múködtették, illetve múködtetik. Kiemelten egykori mesteremnek, Dr. Gaál József professzor úrnak, osztályvezető utódomnak, Dr. Nagy Gábor föorvosnak és a megye szülész-nőgyógyász osztályvezető föorvosainak; $D r$. Szüts Ágnes és Dr. Szücs Ildikó neonatológus osztályveze- tő föorvosoknak, valamint $D r$. Szabó Miklós tanár úrnak, a Semmelweis Egyetem Neonatológiai Intenzív Centruma vezetőjének, a Magyar Perinatológiai Társaság elnökének. Köszönettel tartozom Bánki Krisztina titkárnőnknek és férjének, a számunkra értékes szoftvereket elkészítő informatikus Bánki Lászlónak, valamint Virágh Melinda adminisztrátorunknak, az adatlap összeállításához nyújtott segítségéért.

Anyagi támogatás: A közlemény megírása, illetve a kapcsolódó kutatómunka anyagi támogatásban nem részesült.

A szerző a cikk végleges változatát elolvasta és jóváhagyta.

Érdekeltségek: A szerzőnek nincsenek érdekeltségei.

\section{Irodalom}

[1] Póka, R, Tóth, Z.: Activities and results of obstetric and gynaecological departments in the Nord-Eastern region of Hungary, in 2014. [Az északkelet-magyarországi régió szülészeti-nógyógyászati tevékenysége és eredményei 2014-ben.] Magy. Nőorv. L., 2015, 78(4), 176-183. [Hungarian]

[2] Zeitlin, J., Mohangoo, A., Delnord, M. (eds.): European Perinatal Health Report. Health and care of pregnant women and babies in Europe in 2010. http://www.europeristat.com/reports/european-perinatal-health-report-2010.html

[3] Taufferr, V.: New official rules of obstetrical practice. [Az új szülészeti rendtartás törvény tervezésének előtanulmánya és anyagának ismertetése.] Budapest, 1934. [Hungarian]

[4] Kápolnai, I.: Beginning of obstetrical and gynaecological profession. In: Papp, Z. (ed.): Textbook of obstetrics and gynaecology. [A szülészet-nőgyógyászati hivatás kialakulása. In: Papp, Z. (szerk.): A szülészet-nőgyógyászat tankönyve.] Semmelweis Kiadó, Budapest, 2002. [Hungarian]

[5] Berkö, P., Joubert, K.: The effect of intrauterine development and nutritional status on intrauterine and neonatal mortality. [A magzat méhen belüli fejlettségének és tápláltságának hatása az intrauterin és újszülött-halálozásra.] Orv. Hetil., 2006, 147(29), 1369-1375. [Hungarian]

[6] Berkó, P., Joubert, K.: The effect of intrauterine development and nutritional status on perinatal mortality. J. Matern. Fetal Neonatal Med., 2009, 22(7), 552-559.

[7] Berkö, P., Joubert, K.: The effect of intrauterine development and nutritional status on perinatal, intrauterine and neonatal mortality: The MDN system. In: Ezechi, O. C., Pettersson, K. O. (eds.): Perinatal mortality. InTech, Zagreb, 2012.

(Berkő Péter dr., Miskolc, Benedekalja u. 2., 3508 e-mail: berko.szulesz@bazmkorhaz.hu, peter.berko.dr@gmail.com) 
Melléklet $\quad$ Terhesgondozás és Perinatológiai Ellátás Rizikó Adatlapja (TePERA)

\begin{tabular}{|c|c|c|c|c|c|c|}
\hline \multirow{3}{*}{\multicolumn{3}{|c|}{$\begin{array}{l}\text { VÉDŐNŐ } \\
\text { Védőnő neve: }\end{array}$}} & \multirow{2}{*}{\begin{tabular}{|l|}
34 \\
35 \\
\end{tabular}} & \multirow{2}{*}{\begin{tabular}{|l|} 
Imbecilitas \\
Súlyos mozgáskorlátozottság \\
\end{tabular}} & \multicolumn{2}{|c|}{ A gravida rizikóbesorolása } \\
\hline & & & & & \multirow{2}{*}{\begin{tabular}{|l|}
82 \\
83 \\
\end{tabular}} & \multirow{2}{*}{\begin{tabular}{|l|} 
Rizikómentes \\
Potenciálisan veszélyeztetett terhes \\
\end{tabular}} \\
\hline & & & 36 & Egyéb: & & \\
\hline \multicolumn{3}{|c|}{ Gravida neve: } & 37 & & 84 & Patológiás terhesség \\
\hline \multicolumn{3}{|c|}{ TAJ } & \multicolumn{2}{|c|}{ Háziorvos aláirása: } & \multicolumn{2}{|c|}{ Gondozásért felelós szakorvos aláirása: } \\
\hline \multicolumn{7}{|c|}{ Irányítószám: } \\
\hline \multicolumn{3}{|c|}{ Település: } & \multicolumn{2}{|c|}{ GONDOZÓ SZAKORVOS } & \multicolumn{2}{|c|}{ KÓRHÁZI FELVÉTELKOR } \\
\hline \multirow{2}{*}{\multicolumn{3}{|c|}{ Utca: }} & \multirow{2}{*}{\multicolumn{2}{|c|}{ Neve: }} & \multicolumn{2}{|c|}{ Orvos neve: } \\
\hline & 5 menstruáció: & & & & & \\
\hline & nus: & & Nőg & ógy. előzmények, betegségek & Város & \\
\hline Elsi & anácsadás: & & 38 & Conisatio, portio plastica & OEP- & kód: \\
\hline & trim. $\square$, II. $\square$, III. $\square$ & & 39 & Enucleatio myomatis & 85 & Tanácsadásra nem járt \\
\hline & .... grav., és a ...... szülés lesz & & 40 & Cervicalis császármetszés & 86 & $\begin{array}{r}\text { csak 1-4-szer volt } \\
\end{array}$ \\
\hline & HESSÉGI RIZIKÓTÉNYEZŐK & & 41 & Corporalis császármetszés & 87 & Magzat: nem él \\
\hline & medicinális rizikótényezők & & 42 & Meddőségkezelés: csak stim. th. & 88 & NST monitorizálás nem volt \\
\hline 1 & Írni, olvasni nem tud & & 43 & Insemináció & 89 & kórjelző/gyanús lelet \\
\hline 2 & Iskola: max. általános iskola & & 44 & In vitro fertilizáció & 90 & UH-flowmetria nem volt \\
\hline 3 & középiskola & & 45 & Carcinoma cerv. ut. & 91 & keringés lassult \\
\hline 4 & felsőfokú végzettség & & 46 & Uterus myomat. & 92 & block \\
\hline 5 & Szociális helyzet kedvezőtlen & & 47 & Uterusfejlődési rendellenesség & 93 & reverse flow \\
\hline 6 & Rossz lakás- és higiénés viszonyok & & 48 & Egyéb: & 94 & keringés centralizált \\
\hline 7 & Dohányzik & & & & 95 & UH: kzs. a nyak körül \\
\hline 8 & Alkoholizál & & Terl & sséghez társult anyai betegség & 96 & Felvételi CTG-lelet norm. \\
\hline 9 & Drogfogyasztó & & 49 & Hyperemesis grav. & 97 & kórjelző \\
\hline 10 & Életkora: & & 50 & Szük medence & 98 & Magzatvíz: meconiumos \\
\hline & $<15$ év $\square, 15-19 \square, 20-24 \square$, & & 51 & Fenyegető vetélés-koraszülés & 99 & Egyéb: \\
\hline & $25-34 \square, 35-39 \square, 40+\square$ & & 52 & Cerclage is történt & 100 & \\
\hline 11 & Az anya más országban született & & 53 & Terhességi anaemia $(\mathrm{Hgb}:<11,5 \mathrm{~g} / \mathrm{dl})$ & Felver & on orvos aláirása: \\
\hline & zeti előzmények (száma) & & 54 & Diabetes gest. & & \\
\hline 12 & Nem volt még grav. & & 55 & Rh-isoimmunisatio & & \\
\hline 13 & Eddigi szülések száma: & $\ldots \ldots$ & 56 & Enyhe toxaemia & A SZ & ÜLÉSZETI ESEMÉNYT \\
\hline 14 & $\mathrm{Ab}$. artef. & ....... & 57 & Kp. súlyos praeeclampsia & VEZ & ETŐ ORVOS \\
\hline 15 & Ab. spont. & $\ldots \ldots$ & 58 & Súlyos praeeclampsia & Neve: & \\
\hline 16 & Grav. extraut. & $\ldots \ldots$ & 59 & HELLP szindróma & & \\
\hline 17 & Koraszülés & $\ldots \ldots$ & 60 & Terhesség alatt thrombosis & & Szül. intézmény besorolása: \\
\hline 18 & Halvaszületés & $\ldots \ldots$ & 61 & Terhesség alatt heparinprofilaxis & 101 & Intézeten kívüli szülés \\
\hline 19 & Újszülötthalálozás & $\ldots \ldots$ & 62 & Pyelonephritis & 102 & I. $\square,-$ II. $\square,-$ III. szint $\square$ \\
\hline 20 & Fejlődési rendellenesség & $\ldots \ldots$ & 63 & Súlyos retinabetegség & 103 & \\
\hline 21 & Császármetszés & $2 \ldots \ldots$ & 64 & Nagyfokú soványság & A ter & hesség megszakadt \\
\hline & ôaláirása: & & 65 & Nagyfokú obesitas & 104 & Grav. extraut. \\
\hline & & & 66 & Egyéb: & 105 & Spontán vetélés: I. trim. $\square,-$ II. $\square$ \\
\hline & & & 67 & & 106 & Múvi vet. (orv. jav.): I. tr. $\square,-$ II. $\square$ \\
\hline & IORVOS & & & & 107 & \\
\hline $\mathrm{NeI}$ & & & Maq & at és mellékrészek betegségei & Szüilé & s történt \\
\hline & & & 68 & Valódi túlhordás & 108 & Érett szülés: 37-39. hét $\square, 40+\square$ \\
\hline & sségtől független betegségek & & 69 & Ikerterhesség & 109 & Koraszülés: \\
\hline 22 & Előzményben thrombosis-embolia & & 70 & Többes terhesség (III., IV., V.) & 110 & $<25$. hét $\square, 25-28 . \square$ \\
\hline 23 & Vírusbetegség az I. trimeszterben & & 71 & Felismert fejlődési rendell. (UH) & 111 & 29-32. $\square, 33-36$. hét $\square$ \\
\hline 24 & Igazolt thrombophylia & & 72 & Felismert IUGR: proporcionált & 112 & A magzat otthon született \\
\hline 25 & Szívbetegség (NYHA I-II.) & & 73 & disproporcionált & 113 & mentőben született \\
\hline 26 & (NYHA III-IV.) & & 74 & Krónikus lepényi elégtelenség & 114 & Tervezett otthon szülés volt \\
\hline 27 & Asthma bronchiale & & 75 & Placenta praevia marginalis & 115 & Terminus elött terminálás \\
\hline 28 & Hypertonia essentialis & & 76 & Placenta praevia centralis & 116 & Indított szülés volt \\
\hline 29 & Anaemia $(\mathrm{Hgb}:<11,5 \mathrm{~g} / \mathrm{dl})$ & & 77 & Oligohydramnion & 117 & $\begin{array}{l}\text { Spontán indult: } \\
\text { fájásokkal }\end{array}$ \\
\hline 30 & IDDM & & 78 & Polyhydramnion & 118 & i. e. burokrepedéssel \\
\hline 31 & NIDDM & & 79 & Köldökzsinór a nyak körül & 119 & Spontán hüvelyi szülés volt \\
\hline 32 & Sclerosis multiplex & & 80 & Egyéb: & 120 & Fogó $\square$, VE $\square$ szülés volt \\
\hline 33 & \begin{tabular}{|l|} 
Epilepszia \\
\end{tabular} & & 81 & & 121 & Bracht-Covjanov-féle szülésvezetés \\
\hline
\end{tabular}




\begin{tabular}{|c|c|c|c|c|c|}
\hline 122 & Episiotomia történt & \multicolumn{2}{|c|}{ ÉFT-index $=\mathrm{GK} / \mathrm{S} / \mathrm{H} / \mathrm{T}$} & \multicolumn{2}{|c|}{ ÚJSZÜLÖTT A NIC-BEN } \\
\hline 123 & Császármetszés szülésindulás előtt & \multicolumn{2}{|c|}{$(\mathrm{GK}=$ gesztációs kor, } & \multicolumn{2}{|c|}{ Betegségei } \\
\hline 124 & Császármetszés szülésindulás után & \multicolumn{2}{|r|}{$\mathrm{S}=$ súlystandard-pozíció, } & 198 & Szülési trauma \\
\hline 125 & Cervicalis császármetszés volt & \multicolumn{2}{|r|}{$\mathrm{H}=$ hosszstandard-pozíció, } & 199 & Postasphyxiás szindróma \\
\hline 126 & Corporalis császármetszés volt & \multicolumn{2}{|r|}{$\mathrm{T}=$ tápláltság mutatója, $\mathrm{T}=\mathrm{S}-\mathrm{H})$} & 200 & Légzési elégtelenség \\
\hline 127 & Császárm.+ hysterectomia is történt & & 201 & Tüdővérzés \\
\hline 128 & A császármetszés kérésre történt & \multicolumn{2}{|c|}{ EFT-index: $\ldots \ldots / \ldots \ldots / \ldots \ldots / \ldots \ldots$} & 202 & $\begin{array}{l}\text { Újszülöttkorban keletkezett krónikus } \\
\text { tüdőbetegség }\end{array}$ \\
\hline 129 & Együttszülés volt & \multicolumn{2}{|c|}{ Pozíció az ÉFT-mátrixon } & 203 & Keringési rendszer betegség \\
\hline 130 & EDA történt & \multirow{2}{*}{\multicolumn{2}{|c|}{$\begin{array}{l}\text { Hosszúságstandard } \\
-|N| \omega|\wedge| \sim|\propto| \sim \mid \infty\end{array}$}} & 204 & Veleszületett fertózés \\
\hline 131 & Egyéb: & & & 205 & Postnatalis fertőzés \\
\hline 132 & & \multirow{7}{*}{\multicolumn{2}{|c|}{ 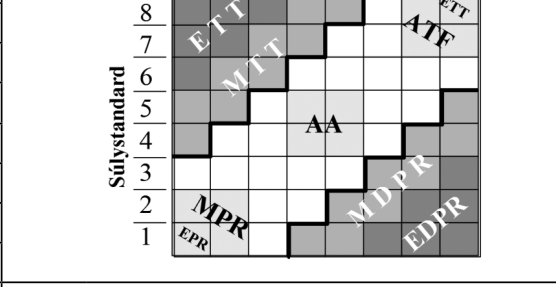 }} & 206 & Nem traumás vérzés \\
\hline \multicolumn{2}{|c|}{ Komplikációk szülés alatt } & & & 207 & Újszülött vérzékenysége \\
\hline 133 & Előzményben császárm. I $\square$, II+ $\square$ & & & 208 & Újszülött haemolyticus betegsége \\
\hline 134 & Fájásgyengeség (Oxytocin infúzió) & & & 209 & Hematológiai rendellenességek \\
\hline 135 & Fenyegető méhrepedés, hegszétválás & & & 210 & Cukoranyagcsere-zavara \\
\hline 136 & Abruptio placentae szülés előtt & & & 211 & Egyéb anyagcserezavar \\
\hline 137 & vajúdás alatt & & & 212 & Endokrinológiai zavar \\
\hline 138 & Fenyegető asphyxia & \multicolumn{2}{|c|}{ Fejlettség és tápláltság alapján: } & 213 & Emésztőszervi rendellenesség \\
\hline 139 & Igazolt asphyxia & 170 & $\mathrm{AA}=$ abszolút arányos & 214 & NEC \\
\hline 140 & Harántfekvés, ferde fekvés & 171 & MPR = mérsékelt. proporc. retardált & 215 & Újszülöttkori görcsök \\
\hline 141 & Medencevégü fekvés & 172 & EPR = extrém proporc. retardált & 216 & Egyéb agyi zavarok \\
\hline 142 & Lábtartás, elóesett láb & 173 & MDPR = mérs. diszproporc. retardált & 217 & ROP \\
\hline 143 & Elhúzódó, nem haladó szülés & 174 & EDPR = extrém diszproporc. retardált & 218 & Egyéb perinatalis állapot \\
\hline 144 & Relatív téraránytalanság & 175 & MTT = mérsékelten túltáplált & 219 & Központi idegr. fejlődési rendell. \\
\hline 145 & Beilleszkedési, tartási, forgási rendell. & 176 & ETT = extrém túltáplált & 220 & Egyéb fejlődési rendellenesség \\
\hline 146 & Súlyos praeeclampsia & 177 & $\mathrm{ATF}=$ arányosan túlfejlett & 221 & Kromoszóma-rendellenesség \\
\hline 147 & Eclampsia, status eclampticus & 178 & Egyéb: & 222 & Terápia: surfactant \\
\hline 148 & III-IV. fokú gátrepedés & Szülé & tvezetó orvos aláirása: & 223 & antibiotikum \\
\hline 149 & Kivérzés, praeshock, shock & & & 224 & keringéstámogatás \\
\hline 150 & Aneszt. szövődmény & & & 225 & kékfény-kezelés \\
\hline 151 & Egyéb: & Újszi & lött sorsa a szülészeten & 226 & vérkészítmény adása \\
\hline 152 & & 179 & Emlőre helyezés 24 órán belül & 227 & infúzió perifériás vénába \\
\hline Csás & ármetszés fó javallatai: & 180 & Látható fejlődési rendellenesség & 228 & centrális vénába \\
\hline $1 \ldots \ldots$ & $\ldots \ldots 2 \ldots \ldots \ldots \ldots 3 \ldots \ldots \ldots \ldots .4 \ldots \ldots \ldots \ldots$ & 181 & Intrauterin infekcióra gyanús & 229 & egésztest-melegítés \\
\hline & & 182 & Lényeges probléma nem volt & 230 & hypothermia-kezelés \\
\hline ÚJS? & ÜLÖTT A SZÜLÉSZETEN & 183 & A szülészetről ment haza & 231 & anyatejtáplálás \\
\hline Szül. & dő: ......... év ........ hó ...... nap & 184 & NIC-be helyeztük át, ennek oka: & 232 & szondatáplálás \\
\hline & $\ldots \ldots \ldots$ óra $\ldots \ldots \ldots$ perc & & & Újsz & lött sorsa: \\
\hline 153 & Szteroidprofilaxis nem történt & & & 233 & Elbocsátva \\
\hline 154 & $>48$ órája történt & & & 234 & 0-6. napos halál \\
\hline 155 & $24-48$ órája történt & Elboc. & átó neonatológus aláirása: & 235 & 7-27. napos halál \\
\hline 156 & $<24$ órája történt & & & Halá & t okozó fó betegségei \\
\hline 157 & Elhalt: & & & & (2) \\
\hline 158 & terhesség alatt: $<28 . \square, 28-36 . \square$, & ANY & A A GYERMEKÁGYBAN & $1 \ldots \ldots$ & 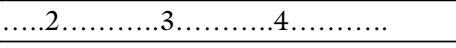 \\
\hline 159 & 37+ héten $\square$ & 185 & Sebgyógyulási zavar & Elboc & átó neonatológus aláirása: \\
\hline 160 & szülés alatt & 186 & Lázas állapot $\left(\min .2\right.$ nap $\left.>38^{\circ} \mathrm{C}\right)$ & & \\
\hline 161 & szülés után szül. osztályon & 187 & Szeptikus állapot & & \\
\hline & & 188 & Thrombosis-embolia & & LÉSZETEN ONLINE \\
\hline Újsz & lött teljes neve: & 189 & Súlyos vérzés - shock & & TSZOLGÁLTATÁS \\
\hline & & 190 & Eclampsia & Dátu & nap \\
\hline Szán & & 191 & Relaparotomia & Vége: & \\
\hline 162 & Egyke $\square$, Iker A $\square$ B $\square$ C $\square$ D $\square$ & 192 & Hysterectomia & & \\
\hline 163 & Neme: fiú $\square$ leány $\square$ & 193 & Aneszt. szövődmény & KITC & LTÉSI ÚTMUTATÓ \\
\hline 164 & Gesztációs kora: & 194 & Aspecifikus anyai betegség & $-\mathrm{Mi}$ & den befejezett terhesség esetén. \\
\hline 165 & Súlya: & 195 & Egyéb: & & Iden újszülöttnek egy adatlap. \\
\hline 166 & Hossza: $\quad \mathrm{cm}$ & 196 & Anyai haláleset/anya kora: & & evek olvashatóak legvenek! \\
\hline 167 & Apgar l perc: $1-3 \square, 4-6 \square, 7-10 \square$ & 197 & $<25$ év $\square, 25-34 \square, 35+\square$ & & \\
\hline 168 & Apgar 5 perc: $1-3 \square, 4-6 \square, 7-10 \square$ & Elboc. & átó szülészorvos aláirása: & & \\
\hline 169 & Resuscitatio történt & & & & \\
\hline
\end{tabular}

